\title{
Investigation of Listeria spp. and Salmonella spp. in curd cheese produced and distributed in the county of Venturosa - Pernambuco, Brazil
}

\author{
[Pesquisa de Listeria spp. e Salmonella spp. em queijo coalho produzido e comercializado no \\ município de Venturosa - Pernambuco, Brasil]
}

\section{"Artigo Científico/Scientific Article"}

\author{
Breno Bezerra Aragão*, Sabrina Cândido Trajano, José Givanildo da Silva, \\ Júnior Mário Baltazar de Oliveira, Larice Bruna Ferreira Soares, Maria Goretti Varejão da Silva, \\ Rita de Cássia Carvalho Maia, Andrea Paiva Botelho Lapenda de Moura
}

Departamento de Medicina Veterinária, Universidade Federal Rural de Pernambuco, Recife-PE, Brasil. *Autor para correspondência/Corresponding author: E-mail: breno.aragao100@ hotmail.com

\begin{abstract}
Curd cheese is one of the most traditional foods produced in the Northeast of Brazil, the production is mainly concentrated in the states of Rio Grande do Norte, Ceará, Pernambuco and Paraíba. Although it has great historical and socioeconomic importance, there is a need for further related studies about the quality control of its production, especially with regard to Listeria spp. and Salmonella spp. given the importance of these microorganisms to public health. Thus, this study aimed to investigate Listeria spp. and Salmonella spp. in samples of curd cheese commercialized in establishments in the municipality of Venturosa, Agreste of the state of Pernambuco, Brazil. Sixty samples of curd cheese were analyzed using the microbiological analysis method according to Normative Instruction n⿳30/2018, Ministry of Agriculture, Livestock and Food Supply (MAPA). No samples were detected for Salmonella spp., however, Listeria grayi was detected in two cheese samples (3.34\%), among the analyzed samples. The presence of $L$. grayi may be associated with hygienicsanitary failures in the stages of obtaining or elaboration of the product. The result obtained in the study reinforces the importance and necessity of the application of Good Manufacturing Practices (GMP) and Good Agricultural Practices (GAP) to obtain a final product safe to the consumer.
\end{abstract}

Keywords: Pathogenic microorganisms; regional product; public health; food safety.

\begin{abstract}
Resumo
O queijo tipo coalho é um dos alimentos mais tradicionais produzidos na região Nordeste do Brasil, a produção concentra-se principalmente nos estados de Rio Grande do Norte, Ceará, Pernambuco e Paraíba. Embora ele tenha uma grande importância histórica e sócio-econômica, há necessidade de mais estudos sobre o controle de qualidade de sua produção, especialmente no que se refere à Listeria spp. e Salmonella spp. dada a importância desses microrganismos para a saúde pública. Assim, este estudo teve por objetivo pesquisar Listeria spp. e Salmonella spp. em amostras de queijo coalho comercializados em estabelecimentos no município de Venturosa, Agreste do estado de Pernambuco, Brasil. Foram analisadas 60 amostras de queijo coalho, utilizando o método de análise microbiológica de acordo com a Instrução Normativa n³0/2018, Ministério da Agricultura, Pecuária e Abastecimento (MAPA). Em nenhuma amostra houve detecção de Salmonella spp., no entanto, foi detectada Listeria grayi em duas amostras de queijo (3,34\%), dentre as amostras analisadas. A presença de L. grayi pode estar associada a falhas higiênico-sanitários nas etapas de obtenção e/ou elaboração do produto. O resultado obtido no estudo reforça a importância e necessidade da aplicação das Boas Práticas de Fabricação (BPF) e das Boas Práticas Agropecuárias (BPA) para a obtenção de um produto final seguro ao consumidor.
\end{abstract}

Palavras-chave: micro-organismos patogênicos; produto regional; saúde pública; segurança alimentar. 


\section{Introdução}

Curd cheese is a typical dairy product from the Northeast of Brazil strictly associated with the lifestyle of the population from this region. It's production rate is higher in the states of Rio Grande do Norte, Ceará, Pernambuco and Paraíba (Queiroz, 2008). Among the artisan cheese types, the curd cheese stands out due to its processing and consuming being associated to the regional culture (Feitosa et al., 1985; Perry, 2004).

Curd cheese is a sub-product of milk highly appreciated by the Northeastern population, reaching a 10 million reais per month profit and being the main income of many families (Almeida et al., 2010). It is mostly produced by small rural producers in a craftsman fashion from raw cow's milk (Ferreira and Freitas Filho, 2008).

According to Normative Instruction $\mathrm{n}^{\mathbf{0}} 30$ (MAPA), which approves the Technical Regulation of Identification and Quality of the Curd Cheese, it is defined as a product obtained by the milk curd which has been subjected to pasteurization or similar thermal process using curd or suitable curing enzymes, completely or not by the action of lactic bacteria, properly sectioned, and distributed in a period of 10 days after the manufacture (BRASIL, 2001b). Although federal legislation requires that the food be subjected to thermal process, the state legislation does not require the pasteurization or thermal processing in the production of the milk used in the curd cheese production (SPRRA, 1999). However, in such cases, the cheese can be manufactured without proper sanitary and basic hygiene.

The cultural identity of the curd cheese and the its artisanal methods of preparation, often rudimentary, make it difficult to establish a modernization in its preparation, resisting the legislation regarding production boundaries and many times escaping standardization under unsatisfactory sanitary conditions (Escobar et al., 2001; Borges et al., 2003; Cavalcante et al., 2007).

Cheese prepared under inadequate sanitary conditions may harbor pathogenic microorganisms, such as bacteria from the genera Salmonella, which have been reported in many studies (Florentino and Martins, 1999; Feitosa et al., 2003; Santana et al. 2008; Sousa et al., 2014). Those findings highlights the importance of a microbiological quality control in this kind of product, once the Brazilian legislation establishes that the total absence of this genera of microorganism in food products is mandatory (BRASIL, 2001a).

Besides bacterial contamination from the genera Salmonella, other microorganisms are also capable of been carried out through cheese, including the genus Listeria spp. that is composed of six species: Listeria monocytogenes, Listeria innocua, Listeria ivanovii, Listeria welshimeri, Listeria seeligeri and Listeria grayi, which cause the infection of listeriosis in both animals and man (Swaminathan, 2001). Food contamination by some Listeria sp. strains can causes high mortality rates $(20-30 \%)$, justifying its relevance in public health among the agents causing food intoxication (Fai et al., 2011).

A study conducted by Arslan and Özdemir (2008) highlighted the resistance to penicillin, chloramphenicol, clarithromycin, amikacin, tetracycline and cefaclor of the following species: L. monocytogenes, L. innocua, L. seeligeri, L. grayi, L. ivanovii and L. welshimeri, isolated from white cheeses. In studies carried out with curd cheese, has already been detected the occurrence of L. monocytogenes (Ramos and Costa, 2003; Duarte et al., 2005; Sousa et al., 2006). Interestingly, although its undeniable importance in public health, more studies are necessary in order to establish the frequency of those pathogens in cheese produced in Brazil (Feitosa et al., 2003).

Therefore, the objective of this study was to investigate the presence of genus Listeria spp. and Salmonella spp. in curd cheese samples from foodstores of Venturosa county, countryside of the state of Pernambuco, Brazil.

\section{Material and Methods}

The statistical method applied for the present study was the non-probability convenience sampling (Sampaio, 1998). Sixty samples were collected from curd cheese commercialized in the county of Venturosa - PE (08 $34^{\circ} 29^{\prime \prime}$ S; 36 $52^{\circ} 27^{\prime \prime}$ $\mathrm{W})$, at 530 meters height in the mesoregion $249 \mathrm{Km}$ from Recife, capital of the state of Pernambuco. The region belongs to a milk-producing area in the state of Pernambuco located at the Agreste mesoregion. Ten different visits to collect samples were performed at each commercial site: A, B, C, $\mathrm{D}, \mathrm{E}$ and $\mathrm{F}$.

Samples were obtained fractionated at the time of purchase in commercial establishments of products of animal origin. The samples did not have 
an inspection seal. The collected samples weighed approximately $500 \mathrm{~g}$, after the acquisition were properly stored in Ziploc ${ }^{\circledR}$ sterile bags, identified and packaged in isothermal boxes with recyclable ice and transported to the Laboratório de Inspeção de Carne e Saúde Pública - LICASP in Departamento de Medicina Veterinária of Universidade Federal Rural de Pernambuco (UFRPE) where the microbiological analysis was performed for the detection of Salmonella spp. and Listeria monocytogenes. For the microbiological analysis, it was used the official analytical methods of Analysis of Products of Animal Origin, established by the MAPA, Normative Instruction $\mathrm{n}^{\mathrm{0}} 30 / 2018$. For Salmonella spp., 25g of the sample was taken, the aliquot was placed in Stomacher ${ }^{\circledR}$ bags with $225 \mathrm{~mL}$ of $1 \%$ peptone water and homogenized for 60 seconds, then, the solution was incubated at $36 \pm 1{ }^{\circ} \mathrm{C}$ for 16 to 20 hours in preenrichment (BRASIL, 2003).

Following the pre-enrichment, the peptone solution was sampled and inoculated in selective broths, adding of $100 \mathrm{uL}$ to Rappaport-Vassiliadis (RV) broth and 1.000uL to Selenite-Cystine (SC) and Muller-Kauffmann tetrathionate (MKT) (Acumedia). Subsequently, the tubes were incubated at $41 \pm 0,5^{\circ} \mathrm{C}$ for 24 to 30 hours for enrichment. Seeding was performed after enrichment using the streak-plate isolation method in Brilliant Green Phenol Red Lactose Sucrose agar (BPLS) (Acumedia) and Rambach agar (Himedia), both incubated at $36 \pm 1^{\circ} \mathrm{C}$ for 18 to 24 hours (BRASIL, 2003).

For L. monocytogenes, 25 grams of sample were weighted and transferred to $225 \mathrm{~mL}$ of Fraser broth, and incubated at $30 \pm 1^{\circ} \mathrm{C}$ for 24 to 48 hours. Then the streak-plate isolation method was performed using the media Palcam (Himedia) and Listeria agar (Merck), and incubated at $30 \pm 1^{\circ} \mathrm{C}$ for 24 to 48 hours (BRASIL, 2003).

After the incubation period, for both Salmonella spp. and L. monocytogenes, three typical colonies from each plate were selected according to the Normative Instruction $n^{\circ} 30 / 2018$ (MAPA) (BRASIL, 2003). All selected colonies were subjected to the Gram staining technique (Stinghen et al., 2002). For those suspected to be Salmonella spp., gram negative rods (Jay, 1994), biochemical tests were performed as determined by the Normative Instruction $n^{\circ} 30 / 2018$ (MAPA) (BRASIL, 2003). For those colonies suspected of being $L$. monocytogenes, the automated method
VITEK $^{\circledR} 2$ compact system bioMerieux (BioMerieux, 2017) was used.

\section{Results and Discussion}

From 60 samples of curd cheese analyzed, Listeria grayi was detected in two samples, both obtained from commercial site F. $L$. monocytogenes and Salmonella spp. were not detect in any of the samples.

Despite the absence of L. monocytogenes and Salmonella spp., contamination of curd cheese may happen during the obtaining of raw material or in any phase of preparation. Ingestion of contaminated cheese or of those obtained from stores with inadequate hygiene measures may cause serious health problems for the consumer due to the variety of pathogens that can be conveyed by cheese (Hoffmann et al., 2004).

Although L. monocytogenes has not been detected in the cheese samples evaluated, it is important to note that bacteria of the genus Listeria may be present in several places in the environment, besides products of animal origin, humans may carry the bacteria (Notermans et al., 1998). Listeria spp. is very selective for in vitro growth, even using specific media for its growth, a circumstance that makes its isolation and identification laborious. This result confirms the findings of Duarte et al. (2005), which found a low incidence $(5.5 \%)$ of $L$. monocytogenes in samples of curd cheese commercialized in the state of Pernambuco.

Although $L$. grayi is not as relevant as $L$. monocytogenes to public health, its presence indicates hygienic-sanitary failures at some stage in the cheese production chain, because this microorganism is found in contaminated water or soil and animal feces (Trabulsi et al., 1999). The presence of $L$. grayi in the food product may suggest a lack of adequate hygiene during the production and/or processing of the milk or neglect the quality control of the water used during cheese processing. Other studies also detected the presence of $L$. grayi in cheeses similar to curd cheese (Silva et al., 1988; Rudolf and Scherer, 2001).

On the other hand, the absence of Salmonella spp. indicates an adequate achievement from the sanitary point of view, taking into account the legal standards required by Resolution-RDC 12, Ministry of Health (MS), which establishes the absence of this group of bacteria for food products 
in Brazil (BRASIL, 2001a). Differently from the present study, Borges et al. (2003) detected high levels of contamination by Salmonella spp. in curd cheeses produced in the state of Ceará, Brazil, that of the 43 samples studied, the presence of Salmonella spp. was detected in 15 samples (34.9\%), and in the same study, the presence of $L$. monocytogenes was also detected in three samples $(6.9 \%)$, with one sample included both agents.

The results obtained in the present study reinforce the importance of the application of Good Manufacturing Practices (GMP) and Good Agricultural Practices (GAP) both in obtaining the raw material and in the elaboration of the product. Further studies are needed in the main contamination points by bacteria of the genus Listeria spp. and Salmonella spp. and in the production chain of the curd cheese produced in the state of Pernambuco, in order to obtain a final product of quality and safe for human consumption.

\section{Conclusion}

Curd cheese commercialized in Venturosa, Pernambuco, meets the standards required by Brazilian legislation regarding the absence of Salmonella spp. and Listeria monocytogenes in dairy products. However, the presence of L. grayi may be associated with hygienic-sanitary failures in the production or elaboration stages of the product, which reinforces the need for Good Manufacturing Practices (GMP) and Good Agricultural Practices (GAP) for the obtaining of a final product safe to the consumer.

\section{Conflicts of Interest}

The authors have no conflicts of interest to declare.

\section{References}

Almeida, S.L.; Paiva, J.F.G.; Guerra, J.R.F. A estratégia de internacionalização de negócios na perspectiva da tradução cultural: o caso da indicação geográfica no agronegócio. Revista Ibero-Americana de Estratégia, 9(2): 74-97, 2010.

Arslan, S.; Özdemir, F. Prevalence and antimicrobial resistance of Listeria spp. in homemade white cheese. Food Control, 19(4): 360-363, 2008.

Borges, M.F.; Feitosa, T.; Nassu, R.T.; Muniz, C.R.; Azevedo, E.H.F.; Figueiredo, E.A.T. Micro-organismos patogênicos e indicadores em queijo coalho produzido no Estado do Ceará, Brasil. Boletim do Centro de Pesquisa de Processamento de Alimentos, 21(1): 3140, 2003.

BRASIL. Ministério da Saúde. Resolução - RDC $\mathrm{n}^{\mathbf{0} 12}$, de 02 de janeiro de 2001a. Disponível em: < http: //portal.anvisa.gov.br/documents 133880/2568070/RDC_12_2001.pdf/ 15ffddf63767-527-bfac-740a0400829b> Accessed in: 05 jun. 2017.

BRASIL. Ministério da Agricultura, Pecuária e Abastecimento. Instrução Normativa $\mathbf{n}^{\circ} 30$ de 26 de junho de 2001b. Disponível em: $<$ https://www.univates.br/unianalises/ media/imagens/Anexo_VIII_ 61948_8.pdf> Accessed in: 05 jun. 2017.

BRASIL. Ministério da Agricultura, Pecuária e Abastecimento. Instrução Normativa no 30 de 26 de junho de 2018. Disponível em: < http://www.imprensanacional.gov. br/materia//asset_publisher/Kujrw0TZC2Mb/content/id/2 9896222/do1-2018-07-13-inst rucaonormativa-n-30-de-26-de-junho-de-201829896212>. Accessed in: 22 aug. 2017.

BIOMERIEUX. Vitek ${ }^{\circledR} 2$ Compact System, 2017. Disponível em: http://www.Biomerie uxdiagnostics.com/vitek-2-gp-id-card>. Accessed in: 06 jul. 2017.

Cavalcante, J.F.M.; Andrade, N.J.; Furtado, M.M.; Ferreira, C.L.L.F.; Pinto, C.L.O.; Elard, E. Processamento do queijo coalho regional empregando leite pasteurizado e cultura lática endógena. Ciência e Tecnologia de Alimentos, 27(1): 205-214, 2007.

Duarte, D.A.M.; Schuch, D.M.T.; Santos, S.B.; Ribeiro, A.R.; Vasconcelos, A.M.M.; Silva, J.V.D.; Mota, R.A. Pesquisa de Listeria monocytogenes e microrganismos indicadores higiênico-sanitários em queijo-coalho produzido e comercializado no estado de Pernambuco. Arquivo do Instituto Biológico, 72: 297-302, 2005.

Escobar, C.A.M.; Leuthier, S.; Antunes, G.; Albuquerque, R.C.L. Avaliação dos pontos críticos na produção de queijo coalho em Pernambuco. Revista do Instituto de Laticínios Cândido Tostes, 56(132): 248-256, 2001.

Fai, A.E.C.; Figueiredo, E.A.T.; Verdin, S.E.F.; Pinheiro, N.M.S.; Braga, A.R.C.; Stamford, T.L.M. Salmonella sp. e Listeria monocytogenes em presunto suíno comercializado em supermercados de Fortaleza 
(CE, Brasil): fator de risco para a saúde pública. Ciência e Saúde Coletiva, 16(2): 657-662, 2011.

Feitosa, T.; Maia, G.A.; Gloria, H.F.; Vasconcelos, M.E.L.; Moura Fé, J.A. Composição Centesimal do queijo tipo "coalho" do Estado do Ceará. Ciência Agronômica, 16(2): 5763,1985 .

Feitosa, T.; Borges, M.F.; Nassu, R.T.; Azevedo, E.H.F.; Muniz, C.R. Pesquisa de Salmonella sp., Listeria sp. e microrganismos indicadores higiênico-sanitários em queijos produzidos no Estado do Rio Grande do Norte. Ciência e Tecnologia de Alimentos, 23(3): 162-165, 2003.

Ferreira, W.L.; Freitas Filho, J.R. Avaliação da qualidade físico-química do coalho comercializado no município de Barreiros - PE.

Revista Brasileira de Tecnologia Agroindustrial, 2(1): 127-133, 2008.

Florentino, E.S.; Martins, R.S. Características microbiológicas do "queijo de coalho" produzido no Estado da Paraíba. Revista Higiene Alimentar, 13(59): 43-48, 1999.

Hoffmann, F.L.; Gonçalves, T.M.V.; Coelho, A.R.; Hirooka, E.Y.; Hoffmann, P. Qualidade microbiologia de queijos ralados de diversas marcas comerciais, obtidos do comércio varejista do município de São José do Rio Preto. Revista Higiene Alimentar, 18(122): 62-66, 2004.

Jay, J.M. Microbiología moderna de los alimentos. Zaragosa: Editorial Acríbia, 1994. Notermans, S.; Dufrenne, J.; Teunis, P.; Chackraborty, T. Studies on the Risk Assessment of Listeria monocytogenes. Journal of Food Protection, 61(2): 244-248, 1998.

Perry, K.S.P. Queijos: aspectos químicos, bioquímicos e microbiológicos. Química Nova, 27(2): 293-300, 2004.

Queiroz, A.A.M.; Bruno, L.M.; Carvalho, A.K.F.; Figueiredo, E.A.T. Caracterização molecular de bactérias ácido láticas com potencial tecnológico para produção de queijo de coalho. Embrapa Agroindústria Tropical. Boletim de Pesquisa e Desenvolvimento, p.54, 2008.

Ramos, S.N.M.; Costa, C.A. Ocorrência de Listeria monocytogenes em queijo artesanal tipo coalho comercializado na cidade de Manaus-AM, Brasil. Acta Amazonas, 33(4): 613-618, 2003.

Rudolf, M.; Scherer, S. High. Incidence of Listeria monocytogenes in European red smear cheese. International Journal of Food Microbiology, 63(1): 91-98, 2001.

Sampaio, I.B.M. Estatística aplicada à experimentação animal. Belo Horizonte: Fundação de Ensino e Pesquisa em Medicina Veterinária e Zootecnia, 1998. 221p.

Santana, R.F.; Santos, D.M.; Martinez, A.C.C.; Lima, Á.S. Qualidade microbiológica de queijo-coalho comercializado em Aracaju, SE. Arquivo Brasileiro Medicina Veterinária Zootecnia, 60(6): 1517-1522, 2008.

Silva, M.C.; Hofer, E.; Tibanau, U.M.A. Incidence of Listeria monocytogenes in cheese produced in Rio de Jenerio, Brazil. Journal of Food Protection, 61(3): 354-356, 1988.

Sousa, R.A.; Figueiredo, E.A.T.; Maia, G.A.; Frizzo, S.E. Incidência de Listeria monocytogenes em queijo de coalho artesanal, comercializado à temperatura ambiente, em Fortaleza, CE. Higiene Alimentar; 20(138): 66-69, 2006.

Sousa, A.Z.B.; Abrantes, M.R.; Sakamoto, S.M.; Silva, J.B.A.; Lima, P.O.; Lima, R.N.; Rocha, M.O.C.; Passos, Y.D.B. Aspectos físicoquímicos e microbiológicos do queijo tipo coalho comercializado em estados do nordeste do Brasil. Arquivo do Instituto Biológico, 81(1): 30-35, 2014.

Stinghen, A.E.M.; Albini, C.A.; ouza, H.A.P.H. Coloração de Gram, como fazer, interpretar e padronizar. Microscience, 2002. 70p.

SPRRA. Secretária de Produção Rural e Reforma Agrária do Estado de Pernambuco. Resolução SPRRA n ${ }^{\circ} 002$ de 19 de abril de 1999. Disponível em: http://webcache.googleusercontent.com/search $? \mathrm{q}=$ cache:8Ir65qbX5WIJ:www.adagro.pe.gov. br/c/document_library/get_file\%3Fp_1_id\%3D 19893\%26folderId\%3D199865\%26name\%3D DLFE-13404.doc $+\& \mathrm{~cd}=1 \& \mathrm{hl}=$ pt-

$\mathrm{BR} \& \mathrm{ct}=\mathrm{clnk} \& \mathrm{gl}=\mathrm{br}>$. Accessed in: 25 mar. 2018.

Swaminathan, B. Listeria monocytogenes. Food Microbiology - Fundaentals and Frontiers, ASM Press, 2001. 410p. 